\title{
Seed Dispersal Spectrum of Woody Species in South Ecuadorian Dry Forests: Environmental Correlates and the Effect of Considering Species Abundance
}

\author{
Andrea Jara-Guerrero ${ }^{1,4}$, Marcelino De la $\mathrm{Cruz}^{2}$, and Marcos Méndez ${ }^{3}$ \\ ${ }^{1}$ Instituto de Ecología, Universidad Técnica Particular de Loja, CP.: 11-01-608, Loja, Ecuador \\ ${ }^{2}$ Departamento de Biología Vegetal, Universidad Politécnica de Madrid, 28040 Madrid, Spain \\ ${ }^{3}$ Área de Biodiversidad y Conservación, Universidad Rey Juan Carlos, E-28933 Móstoles, Spain
}

\begin{abstract}
This study examines the seed dispersal spectrum of the tropical dry forests of Southern Ecuador, in an effort to contribute to the knowledge of the complex dynamics of tropical dry forests. Seed dispersal spectrum was described for a total number of 160 species. Relationships of dispersal syndromes with plant growth form and climatic seasonality were explored. For a subset of 97 species, we determined whether dispersal spectrum changes when species abundance, in addition to species number, is taken into account. The same subset was used to relate dispersal syndromes with the environmental conditions. Zoochorous species dominated in the studied community. When considering the individual abundance of each species, however, anemochory was the prevalent dispersal syndrome. We found a significant difference in the frequency of dispersal syndromes among plant growth forms, with epizoochory only occurring in shrub species. The dispersal spectrum was dependent on climatic seasonality. The largest proportion of anemochorous species fructified during the dry season, while zoochorous diaspores dominated during the rainy season. A fourthcorner analysis indicated that the seed dispersal spectrum of Southern Ecuador dry forests is controlled by environmental conditions such as annual precipitation, annual temperature range or topography. Our results suggest that spatio-temporal changes in the environmental conditions may affect important ecological processes for dispersal. Thus, the predominance of one syndrome or another may depend on the spatial variation of environmental conditions.
\end{abstract}

Abstract in Spanish is available at http://www.blackwell-synergy.com/loi/btp.

Key words: dispersal syndromes; fruiting phenology; growth forms; Neotropical dry forest.

SEED DISPERSAL PLAYS A FUNDAMENTAL ROLE IN THE COLONIZATION OF NEW HABITATS, population dynamics as well as in species interactions, community structure and diversity (Van der Pijl 1969, Howe \& Smallwood 1982, Willson et al. 1990, Hughes et al. 1994, Morales \& Carlo 2006). Because of this, it is a key factor in conservation biology and restoration management (Strykstra et al. 2002, Navarro et al. 2009).

The diaspores of many plant species have developed specialized morphological structures, which enable them to make use of biotic and abiotic dispersal vectors (Van der Pijl 1969, Wenny 2001, Schulze et al. 2002). These morphological structures, as well as diaspore color, chemical characteristics of the pulp and phenological events of plants associated with a particular dispersal mode, are known as 'dispersal syndromes' (Van der Pijl 1969, Gottsberger \& Silberbauer-Gottsberger 1983, Howe \& Westley 1988). The proportion of dispersal syndromes in a particular vegetation type is known as the 'dispersal spectrum' (Howe \& Smallwood 1982, Hughes et al. 1994, Arbeláez \& Parrado-Rosselli 2005). The study of dispersal spectra has interested researchers for several decades (Van der Pijl 1969, Frankie et al. 1974, Gentry 1982, Howe \& Smallwood 1982, Howe \& Westley 1988). It is seen as a way of documenting fundamental aspects of the functional diversity in ecosystems.

The dispersal spectrum of a plant community can be influenced by several factors. First, dispersal syndromes are related to plant growth form. For example, zoochory and autochory are widely dis- tributed among shrubs and treelets of the understory, whereas anemochory is more frequent among canopy trees (Wikander 1984, Justiniano \& Fredericksen 2000, Griz \& Machado 2001, Butler et al. 2007). In general, this pattern is explained by the reduction of wind speed in the forest understory (Wikander 1984, Justiniano \& Fredericksen 2000, Griz \& Machado 2001). However, in some tropical dry forests, there is a great proportion of anemochory among shrubs, favored possibly by plant deciduousness, which allows a higher wind circulation in the forest understory (Griz \& Machado 2001).

Second, physical conditions influence the dispersal spectrum. There is a broad consensus that anemochorous plants are relatively common in dry habitats, while those adapted for zoochory dominate in wet habitats (Howe \& Smallwood 1982, Jordano 2000, Herrera \& Pellmyr 2002). Quantitative correlations between physical conditions and dispersal spectrum have, however, rarely been established (see, however, Butler et al. 2007). Some studies found that certain environmental conditions, such as precipitation, temperature, soil nutrient status or canopy closure influence the relative presence of a dispersal syndrome in a particular site (Willson et al. 1990, Bullock 1995). For example, an association of zoochory and those sites with greater moisture and soil fertility has been suggested (Gentry 1982, Willson et al. 1990). At a local level, this pattern could be related with topography (Wikander 1984, Bullock 1995).

Third, for tropical dry forests, several authors report a seasonal pattern in dispersal spectra. Anemochorous species fruited during the dry season, while zoochorous species fruited throughout the rainy season (Frankie et al. 1974, Gottsberger \& SilberbauerGottsberger 1983, Ibarra-Manríquez et al. 1991, Oliveira \& 
Moreira 1992, Bullock 1995, Batalha \& Mantovani 2000, Justiniano \& Fredericksen 2000, Griz \& Machado 2001).

Variation in the dispersal spectrum in relation to spatio-temporal variation of environmental conditions could indicate important ecological factors for dispersal. For example, dry seasons lead to leaf shedding that favors anemochory (Wikander 1984, IbarraManríquez et al. 1991, Griz \& Machado 2001), while zoochorous fleshy fruits require water and suitable temperature to mature which occur in rainy seasons or wetter sites (Herrera \& Pellmyr 2002). Nevertheless, these relationships between dispersal syndromes and physical conditions are empirically based and causality is difficult to disentangle. For instance, Hughes et al. (1994) and Butler et al. (2007) argue that a relationship between physical conditions and the frequency of dispersal syndromes has lesser importance, and rather results from the indirect influence on plant growth form and seed size. Spatio-temporal changes in dispersal syndromes can also be causally related to physical conditions or be a by-product of species turnover. Statistical tools such as the fourth-corner analysis currently allow relating dispersal syndromes and environmental conditions with a robust and simple statistical procedure, and permit disentangling some of the effects usually confounded in traditional regression approaches. Such techniques can shed light on the issues raised above.

As in other analyses of functional diversity, a potential limitation of current generalizations about dispersal spectra is that they usually ignore the relative abundance of each species (Wikander 1984, Batalha \& Mantovani 2000, Justiniano \& Fredericksen 2000, Griz $\&$ Machado 2001, Ragusa-Netto \& Silva 2007). For example, in the semi-deciduous cerrado of Brazil, zoochory was the dominant dispersal syndrome at the species level, but anemochorous species were represented by a greater number of individuals (Gottsberger \& Silberbauer-Gottsberger 1983). Such mismatches suggest that different causal factors could determine species richness and the success of species with certain syndromes, and consequently, dominance and species richness in plant communities.

In general, seed dispersal in tropical dry forests has received little attention compared with rain forests. Although some studies exist on dispersal spectra for Neotropical dry forests, data are very superficial and scattered, which is worrying considering that they hold several of the most endangered ecosystems in the world (Best \& Kessler 1995, Vázquez et al. 2001, Espinosa et al. 2011). In order to enhance our knowledge about the functional diversity of these forests, the present study examined the seed dispersal spectrum of woody species in tropical dry forests of Southern Ecuador. We answered the following questions: (1) Do dispersal syndromes vary among plant growth forms (tree, treelet and shrub)? (2) Does the relative frequency of dispersal syndromes differ between the rainy and dry seasons? (3) Does the dominance of dispersal syndromes change if species abundance, in addition to species number, is taken into account? (4) Are dispersal syndromes related to environmental conditions? We also summarize the existing data on dispersal spectra for other Neotropical dry forests, and compare them with the results obtained in this study, in an effort to improve the generality of the knowledge of dispersal in tropical dry forests.

\section{METHODS}

STUDY AREA.-The studied dry forests are located in Loja and El Oro Provinces, between latitudes $3^{\circ} 3^{\prime} 11^{\prime \prime}$ and $4^{\circ} 37^{\prime} 28^{\prime \prime} \mathrm{S}$ and between longitudes $79^{\circ} 14^{\prime} 37^{\prime \prime}$ and $80^{\circ} 25^{\prime} 46^{\prime \prime} \mathrm{W}$ (Fig. S1). This area comprises some of the largest and best preserved remnants of tropical dry forest of the Tumbesian biogeographic region, one of the most important areas of endemism in the world, but at the same time, one of the most threatened (Best \& Kessler 1995). Nowadays, anthropogenic pressure has led to this area being dominated by agricultural patches interspersed with forest remnants. The climate is characterized by a dry season extending from May to November and a rainy season extending from December to April (Aguirre \& Kvist 2005). Mean annual temperature is between $20^{\circ}$ and $26^{\circ} \mathrm{C}$, and the annual precipitation is between 300 and $700 \mathrm{~mm}$ (Aguirre $\&$ Kvist 2005). Elevation ranges between 50 and $800 \mathrm{~m}$ as (Vázquez et al. 2001). For the studied area, Aguirre et al. (2006a) found 238 of the 275 woody species recorded for dry vegetation types of Ecuador.

DATA SAMPLING.-We obtained a list of 203 woody native species of Southern Ecuador from the inventories of Aguirre and Kvist (2005) and Aguirre et al. (2006a, 2006b). The species were classified according to growth form into trees, treelets or shrubs, following Harling and Anderson (1977-2007), Jørgensen and León-Yánez (1999) and Pennington et al. (2004) (Table 1). A literature review (see the supporting information Appendix S1) as well as field

TABLE 1. Growth forms and diaspore traits considered in this study.

\begin{tabular}{|c|c|}
\hline Parameter & Category \\
\hline Growth form & $\begin{array}{l}\text { Tree, treelet or shrub (Harling \& Anderson 1977-2007, } \\
\text { Jørgensen \& León-Yánez 1999, Pennington et al. 2004) }\end{array}$ \\
\hline Fruit type & $\begin{array}{l}\text { Dry indehiscent: achene, achenetum, capsule, legume or } \\
\text { mericarp; dry dehiscent: capsule, follicle, legume or } \\
\text { craspedium; fleshy: berry, baccarium, drupe, pseudodrupe, } \\
\text { syconium or sorosis (Spjut 1994) }\end{array}$ \\
\hline Diaspore type & Fruit or seed \\
\hline $\begin{array}{l}\text { Diaspore } \\
\text { morphology }\end{array}$ & $\begin{array}{l}\text { Sticky anthocarp, hooked spines, arists, stiff hairs, plumed, } \\
\text { samara, woolly, pappus, caruncle, sarcotesta, aril, mucilage, } \\
\text { fleshy periant, fleshy pulp, explosive dehiscence or without } \\
\text { structures (van der Pijl 1969) }\end{array}$ \\
\hline Diaspore color & $\begin{array}{l}\text { Green, brown, yellow, orange, red, white, black, blue/purple } \\
\text { or mixed (Janson 1983, Wheelwright \& Janson 1985, Link } \\
\text { \& Stevenson 2004, Chen } \text { et al. 2004) }\end{array}$ \\
\hline $\begin{array}{l}\text { Diaspore } \\
\text { protection }^{\mathbf{a}}\end{array}$ & $\begin{array}{l}\text { Protected (mature pulp covered by a husk, distinct hard, } \\
\text { nonnutritious layer as a barrier to feeding or digestion) or } \\
\text { unprotected (fruits with a soft, flexible skin, with a thickness } \\
<10 \% \text { of the thickness of the smallest fruit dimension) } \\
\text { (Janson 1983, Link \& Stevenson 2004) }\end{array}$ \\
\hline
\end{tabular}

${ }^{a}$ The diaspore protection was determined only for endozoochorus and sinzoochorus species. 
TABLE 2. Variables describing environmental conditions in 109 plots of dry forest of Macará and Zapotillo (Loja province) (for details, see Espinosa et al. 2011).

\begin{tabular}{lccc}
\hline Environmental variables & Scale & Range of values & Statistic used in the fourth-corner analysis \\
\hline Inclination & Continuous & $0-45^{\circ}$ & Pseudo- $F$ \\
Annual temperature range & Continuous & $13.80-16.60^{\circ} \mathrm{C}$ & Pseudo- $F$ \\
Annual precipitation & Continuous & $270-1284 \mathrm{~mm}$ & Pseudo- $F$ \\
Rainfall in the driest month & Continuous & $0-4 \mathrm{~mm}$ & Pseudo- $F$ \\
Soil moisture & Continuous & $1.05-28.7 \%$ & Pseudo- $F$ \\
Soil organic matter & Continuous & $0.03-13.02 \%$ & Pseudo- $F$ \\
Topography & Categorical & Valley, slope or ridge & Pearson $\chi^{2}$ \\
Intervention grade & Ordinal & $1:$ low; 2: medium; 3: high & Pseudo- $F$ \\
\hline
\end{tabular}

observations and examination of herbarium specimens (Herbario de la Universidad Técnica Particular de Loja, Herbario Loja and Herbario Nacional del Ecuador), allowed us to assign a dispersal syndrome to 160 species of this list (which represent 121 genera and 50 families). Dispersal syndromes were assigned to each species based on diaspore traits such as fruit type, morphology and color of the diaspore and, for diaspores with fleshy structures, we also registered the existence or not of protective structures that might hinder consumption by animals (Janson 1983, Link \& Stevenson 2004) (Table 1).

The species were classified into four general dispersal syndromes (Van der Pijl 1969): autochory, anemochory, zoochory and polychory. Autochory was further divided into active or passive. Active autochory includes diaspores propelled explosively, while passive autochory refers to the so-called passive ballists, triggered by passing animals, wind or raindrops. So-called barochorous (diaspores simply released and falling to the ground) were also included in the latter group (Gottsberger \& Silberbauer-Gottsberger 1983).

Following Augspurger (1986), anemochorous diaspores were further divided into six morphological groups, according to their aerodynamic structures: undulator, floater, autogyro, rolling-autogyro, helicopter or tumbler.

Zoochorous species were divided into four subcategories (Van der Pijl 1969): (a) epizoochory, defined as the passive transport through the adhesion of diaspores to feathers or hair of animals; (b) sinzoochory, assigned to diaspores collected and stored in caches by rodents, as well as diaspores actively transported by animals that feed on parts of them but do not ingest the seeds; (c) endozoochory, when the diaspore is actively ingested and seeds are usually evacuated intact; and (d) myrmecochory, assigned to diaspores with elaiosomes or those actively transported by ants.

Some species have seeds that are polymorphic for dispersal structures, or have two dispersal modes that could operate sequentially (Willson et al. 1990, Griz \& Machado 2001). Diaspores of this type were assigned to a separate category called 'polychory' (Van der Pijl 1969, Cousens et al. 2008).

Furthermore, we assigned each species to one of three fruit types: fleshy, dry dehiscent and dry indehiscent, as the proportion of species in these simple categories has been suggested to correlate with environmental variables (Knight 1986, Willson et al. 1989,
Tabarelli et al. 2003). To determine the relationship among dispersal syndromes and climatic seasonality, we collected data about fruiting phenology both from field observations and from labels of herbarium specimen collected in dry forest localities.

In addition, we assigned dispersal syndromes to all (97) woody species recorded in 109 plots of dry forest located in the south of our study area (Fig. S1). These plots were established on 48 forest stands with a stratified sampling design, trying to encompass the whole range of physical conditions present in the tropical dry forests of Southern Ecuador (Espinosa et al. 2011). Two or three plots of $20 \times 20 \mathrm{~m}$ were sampled per forest stand. The total area sampled was 5.45 ha (for further details, see Espinosa et al. 2011). In each plot, eight variables describing environmental conditions were also recorded (Table 2). These variables were selected based on their documented relationship with dispersal syndromes (Knight 1986, Willson et al. 1990, Bullock 1995, Tabarelli et al. 2003), and on their relevance to other ecological parameters such as species richness and composition in different plant communities (Espinosa et al. 2011). These data were used to analyze the relationship among dispersal traits and environmental conditions. In each plot, we also recorded the number of individuals of each species in order to calculate the seed dispersal spectrum based on individual abundance, i.e., as the percentage of individuals having each dispersal syndrome over the total number of individuals recorded in all the plots.

STATISTICAL ANALYSES.-Differences in the frequency of major dispersal syndromes among categories of growth form (tree, treelet and shrub) and among climatic seasons (rainy and dry) were analyzed by means of contingency tables ( $G$-test). We used also $G$-tests to analyze the frequency of major dispersal syndromes in the 109 plots of dry forest, taking into account the number of individuals of each species.

We used the set of floristic abundances and the environmental data from the 109 dry forest plots to analyze the relationship between two dispersal traits (dispersal syndromes and type of fruit) and environmental conditions. For this, we used the new version of the fourth-corner analysis (Legendre et al. 1997, Dray \& Legendre 2008). Fourth-corner analysis directly relates an $\mathrm{R}$ matrix of environmental variables (Table 2) to a $Q$ matrix of species traits (dispersal syndromes and fruit types), by means of an $\mathrm{L}$ matrix of species abundance measured in the field (Dray \& Legendre 2008, 
Aubin et al. 2009). A statistic is computed for each pair of species traits and environmental variables. Depending on the type of variable, this statistic is a Pearson $\chi^{2}$ (for two qualitative variables); or a pseudo- $F$ and a correlation ratio $\eta^{2}$ (for one quantitative and other qualitative variable) (Legendre $e t$ al. 1997, Dray \& Legendre 2008). Moreover, $S_{\mathrm{RLQ}}$, a global multivariate statistic that links the complete matrices $\mathrm{R}$ and $\mathrm{Q}$ is computed as the sum of all $\chi^{2}$ and $\eta^{2}$ values in the fourth-corner matrix. For computing this statistic, quantitative variables are standardized to mean 0 and variance 1 and qualitative variables are coded using dummy variables (Dray $\&$ Legendre 2008).

The significance of all fourth-corner statistics can be tested using different permutation models (Dray \& Legendre 2008). In this study we used a model where cell values in the $\mathrm{L}$ matrix are permuted within each column. This model tests the null hypothesis that the species are randomly distributed with respect to abiotic environmental conditions (Aubin et al. 2009). This analysis was carried out using the ade4 package (Dray et al. 2007) in the R software (R environment Core Team 2010).

\section{RESULTS}

DESCRIPTION OF DISPERSAL SYNDROMES.-Our description of dispersal syndromes is based on the total data set $(N=160)$. Zoochory was the dominant dispersal syndrome in the studied community (54\%, 87 species) followed by anemochory ( $28 \%, 44$ species) and autochory $(15 \%, 24$ species). The remaining species were assigned to the polychory category.

Fleshy fruits represented the 44 percent (70 species) of all the species, followed by dehiscent fruits (33\%, 53 species) and indehiscent fruits $(23 \%, 37$ species). Fruits were the dominant dispersal units $(69.4 \%, 111$ species), while seeds with specialized dispersal structures occurred in 30.6 percent of all species, mainly the anemochorous ones.

Among zoochorous species, 88 percent $(76$ species) were endozoochorous, while epizoochorous, sinzoochorous and myrmecochorous species were found in very low percentages $(5 \%$, $5 \%$ and $2 \%$, respectively). Fruits with fleshy pulp were the most common berween endozoochorous species, especially drupes (42\%) and berries (30\%).

We found nine different colors among the diaspores of 80 endozoochorous and sinzoochorous species. Brightly colored diaspores were clearly dominant. Only 9 percent of these species presented some physical protection against feeding (Table 1). This attribute was most evident in dull colored diaspores (brown, yellow and orange).

Most anemochorous species (52.3\%) presented dry dehiscent fruits, and used seed structures for dispersal. A second group (47.7\%) presented fruits with structures modified for dispersal, which reduce rates of descent. The six morphological groups of anemochorous diaspores were present. The rolling-autogyro structures were prevalent $(31.8 \%, 14$ species), followed by those with helicopter structures $(18.2 \%, 8$ species), autogyro and undulator structures (both 15.9\%, 7 species) and floater and tumbler structures (both $6.8 \%, 3$ species).
TABLE3. Number of species showing different dispersal syndromes and growth forms among 160 woody species in the tropical dry forests of Southern Ecuador.

\begin{tabular}{lrcc}
\hline & \multicolumn{3}{c}{ Growth form } \\
\cline { 2 - 4 } & Tree & Treelet & Shrub \\
\cline { 2 - 4 } Dispersal syndrome $^{a}$ & 36 & 19 & 35 \\
Zoochory & 32 & 17 & 27 \\
Endozoochory & 1 & 1 & 3 \\
Myrmecochory & 3 & 1 & 0 \\
Sinzoochory & 0 & 0 & 5 \\
Epizoochory & 28 & 3 & 13 \\
Anemochory & 5 & 1 & 1 \\
Autogyro & 6 & 1 & 9 \\
Rolling autogyro & 7 & 0 & 0 \\
Floater & 5 & 1 & 2 \\
Helicopter & 3 & 0 & 0 \\
Undulator & 2 & 0 & 1 \\
Tumbler & 13 & 3 & 7 \\
Autochory & 3 & 0 & 6 \\
Active & 10 & 3 & \\
Passive & & & \\
\hline
\end{tabular}

${ }^{2}$ Polychorous species have been separated in the corresponding syndromes, contributing one case to each dispersal syndrome implied.

Among autochorous species, passive autochory was dominant and only seven species $(29.2 \%)$ had an active dispersal favored by fruits with explosive dehiscence.

We registered five polychorous species. Three of these species (Cnidoscolus aconitifolius, Croton menthodorus and Croton wagneri) presented fruits with explosive dehiscence, which is characteristic to active autochorous diaspores, and seeds with elaiosome, characteristic of myrmecochorous diaspores. The other two species (Erythrina spp.) exhibited characteristics of both autochory and zoochory.

GROWTH FORM AND DISPERSAL SYNDROMES.-The $G$-test revealed significant differences in the frequency of dispersal syndromes among growth forms $\left(G_{2}=24.526, P=0.006\right)$. Zoochory was the dominant dispersal syndrome in the three studied growth forms, mainly represented by endozoochorous species $(35.6 \%$ trees, $18.9 \%$ treelet and $30 \%$ shrubs). Endozoochorous, sinzoochorous and myrmecochorous species were also present in the three categories, while epizoochory occurred only in shrub species (Table 3).

Trees presented the greatest variety of anemochorous diaspores (Table 3), with a dominance of floater diaspores (25\%), followed by rolling-autogyro diaspores (21.4\%), autogyro (17.9\%) and helicopter $(17.9 \%)$. By contrast, rolling-autogyro diaspores were dominant among treelet and shrub species. Floater and undulator diaspores were found only among tree species (Table 3).

Autochorous diaspores were registered in the three growth forms. The greatest frequency of active autochory was found among shrub species corresponding to Euphorbiaceae, Fabaceae and Mimosaceae families. 




FIGURE 1. Monthly variation in the number of fruiting species belonging to the main dispersal syndromes in the tropical dry forests of Southern Ecuador $(N-54$ species). Average monthly rainfall is represented with a continuous line. Rainfall data were obtained from the Worldclim 1.4 data base (Hijmans et al. 2005).

Climatic SEASONALITY AND DISPERSAL SYNDROMES.-We collected phenological information for 54 species. In general, fruiting phenology differed among dispersal syndromes $\left(G_{2}=12.626, P=0.002\right)$. The largest proportion of anemochorous species fructified during the dry season, while zoochorous diaspores fructified during the rainy season (Fig. 1). Autochorous species also had a marked peak of fruiting during this season (Fig. 1). No polychorous species were recorded in this group.

INDIVIDUAL ABUNDANCE AND DISPERSAL SYNDROMES.-A total of 3392 individuals (corresponding to 97 species) were recorded in the 109 forest plots. Another 132 individuals could not be identified to species and therefore were not included in the analysis. Zoochorous species were prevalent among the 97 species recorded (55\%, 54 species) followed by anemochorous $(28 \%, 28$ species), autochorous $(15 \%, 15$ species) and polychorous species (1\%, 1 species). However, when the frequency of dispersal syndromes was analyzed based on individual abundance, the dispersal spectrum changed $\left(G_{2}=20.512, P=0.0001\right)$. The greatest proportion of individuals corresponded to anemochorous species $(51.56 \%, 1749$ individuals), while zoochory represented only the 34.6 percent (1174 individuals) followed by autochory $(11.5 \%, 391$ individuals $)$ and polychory ( $2.3 \% 78$ individuals).

In terms of individual abundance, endozoochory remained as the dominant strategy within zoochory $(29.4 \%$ of total individuals), while sinzoochory and epizoochory were underrepresented (3.3\% and $1.9 \%$, respectively).

ENVIRONMENTAL CONDITIONS AND DISPERSAL TRAITS.-The fourthcorner analysis revealed a significant relationship among dispersal traits and all environmental variables considered with the exception of soil organic matter $\left(S_{\mathrm{RLQ}}=0.438, P=0.001\right.$, Table $\left.S 1\right)$.
Twenty-two statistics in the fourth-corner matrix were significant (Fig. 2, Table S2). According to this analysis, both anemochory and epizoochory were associated with sites that showed special homogeneity with respect to the range of annual temperature. The correlation ratio showed that both were negatively correlated with this range $\left(\eta^{2}=-0.187\right.$ and -0.04 , respectively), i.e., they were favored in sites with small variation in annual temperature. Both syndromes were associated to annual precipitation but in this case responded in opposite ways: anemochory was associated with high values (wetter sites) and epizoochory with low values (dryer sites, $\eta^{2}=0.124$ and -0.022 , respectively). Epizoochory was also associated with the sites that get the smallest rainfall during the driest month $\left(\eta^{2}=-0.155\right)$.

A positive relation was found between endozoochorous species and slope sites while epizoochorous species had a major presence on ridge sites. Sinzoochorous and autochorous species were not significantly related to any environmental variables studied.

Dry dehiscent and indehiscent fruits are mostly related to anemochorous and autochorous dispersal (the supporting information Appendix S1), and showed a similar partern with respect to environmental conditions, being present mainly in sites with lower soil moisture (dry indehiscent fruits, $\eta^{2}=-0.073$ ) and having lower precipitation during the driest month and lower annual temperature range (dehiscent fruits $\eta^{2}=-0.097$ and -0.089 , respectively). Dry dehiscent and fleshy fruits were more frequent than expected by the permutation model in slopes while dry dehiscent fruits were more frequently associated to valley sites.

\section{DISCUSSION}

The seed dispersal spectrum of the studied Southern Ecuador dry forests was characterized by the dominance of zoochory, followed by anemochory, and small percentages of autochorous and polychorous species. These results are consistent with those reported for other Neotropical dry forests (Table 4). Among zoochorous species, endozoochory was the prevalent strategy, while for anemochory, six morphological groups with similar percentages were found. Thus, functional diversity was higher for anemochorous compared with zoochorous species.

Among zoochorous species, the high proportion of unprotected diaspores with bright colors could suggest that bird dispersal was prevalent (Van der Pijl 1969, Janson 1983, Link \& Stevenson 2004, Cousens et al. 2008), in contrast with the low proportion of protected diaspores with dull colors, which are preferentially consumed by mammals (Van der Pijl 1969, Janson 1983, Link \& Stevenson 2004, Cousens et al. 2008). Nevertheless, the scarcity of fleshy fruits that is usually observed during the dry season in this type of vegetation could force a wide range of animals to feed on any type of fruit that is available (Griz \& Machado 2001).

Surprisingly, when we examined the individual abundance of each species, we found a shift in dominance from zoochory to anemochory. This means that, although there is a high variety of zoochorous species, most of the studied community corresponds to individuals which do not provide any reward for dispersing animals. Therefore, from a functional perspective of dispersal 


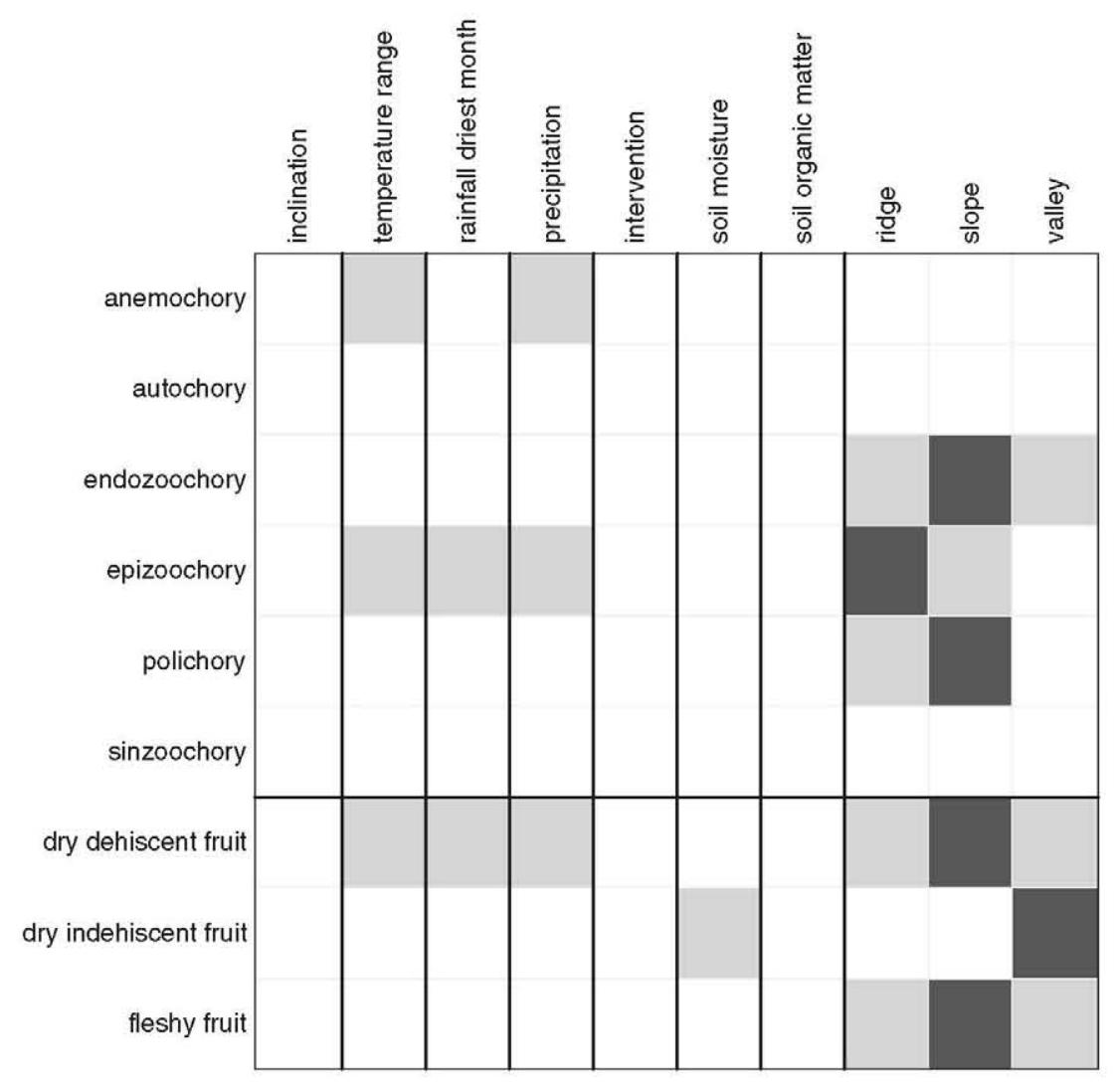

FIGURE 2. Results of fourth-corner test comparing environmental variables with dispersal syndromes and fruit type. White cells: nonsignificant results, soft gray: significantly negative deviations from the permutational null model; dark gray: significantly positive deviations. First seven columns (slope to soil organic matter): normalized measures of within-group homogeneity (within group sum of squares divided by the total sum of squares). Three last columns (ridge to valley): cell values of the contingency table analyses.

interactions, we must consider not only the proportion of species by dispersal syndrome, but also the abundance of each species. This shift, together with the existing relationships between environmental conditions and dispersal syndromes (see below) may be due to the relative abundance of habitats that are suitable for species with different dispersal syndromes. In this particular case, it is possible that relative abundance of suitable habitats for anemochorous species is higher than relative abundance of suitable habitats for zoochorous species. Hence the predominance of one syndrome or another may depend on the spatial heterogeneity in environmental conditions. In addition, consideration of the phylogenetic signal in the study of dispersal syndromes also deserves future attention in elucidating the relative frequency of dispersal syndromes using species or individual abundances.

Dispersal syndromes showed an association with growth form, as shown in previous studies (Van der Pijl 1969, Wikander 1984, Willson et al. 1990, Justiniano \& Fredericksen 2000, Griz \& Machado 2001). In particular, epizoochory was found only among shrubs. This is consistent with the need for contact between hooked or sticky diaspores with the body of passing animals, which constrains the growth form of the species having this dispersal syndrome (Willson et al. 1990). Contrary to what has been reported for other tropical dry forest sites, endozoochory was not restricted to treelets and shrubs but was equitably present in all growth forms (Wikander 1984, Justiniano \& Fredericksen 2000). Further research is needed to explain this finding.

Anemochory was observed mainly among tree species, but contrary to what has been reported for other communities, it also occurred among treelets and shrubs. According to Griz and Machado (2001), this is related to the loss of foliage that affects both trees and shrubs in dry forests, which allows wind circulation not only at the canopy, but also through the understory. However, there was a difference in the types of anemochorous strategies among growth forms. Floater and undulator diaspores were prevalent among tree species, which may be related to their rapid rates of fall (Augspurger 1986, Ibarra-Manríquez. et al. 1991, Cousens et al. 2008), so their release from greater heights would allow better use of horizontal wind force and reaching longer distances (Cousens et al. 2008). Conversely, diaspores with rolling-autogyro structures were more common among shrub and treelet species. These diaspores have slow rates of fall that allow dispersing the seeds away from the mother plant even when released from a moderate height (Augspurger 1986, Cousens et al. 2008).

Despite being a rare syndrome in the community, autochory was found in the three growth forms considered. Hughes et al. (1994) note that distances achieved by autochory are constrained by the physical mechanism itself and rarely exceed a few meters. So, effective 
TABLE 4. Seed dispersal spectrum for other seasonally Neotropical dry forests. Dispersal syndrome (ane, anemochory; aut, autochory; zoo, zoochory; pas, passive autochory). growth form (T, tree; $S$, shrub; $C L$, climber; $C T$, cactus; $H$, herb; P, phanerophytes; $C H$, chamaephytes; $G$, geophytes).

\begin{tabular}{|c|c|c|c|c|c|c|c|c|c|c|c|}
\hline \multirow[b]{2}{*}{ References } & \multirow[b]{2}{*}{ Locality } & \multirow[b]{2}{*}{$\begin{array}{l}\text { Altitude } \\
\text { (m asl) }\end{array}$} & \multirow[b]{2}{*}{$\begin{array}{l}\text { Rainy } \\
\text { period } \\
(\mathrm{mo})\end{array}$} & \multirow[b]{2}{*}{$\begin{array}{c}\text { Mean annual } \\
\text { rainfall } \\
(\mathrm{mm})\end{array}$} & \multirow[b]{2}{*}{ Growth form } & \multicolumn{4}{|c|}{ Dispersal syndrome } & \multicolumn{2}{|c|}{$\begin{array}{c}\text { Dominant syndrome } \\
\text { by season }(\%)\end{array}$} \\
\hline & & & & & & $\begin{array}{c}\text { Anemochory } \\
(\%)\end{array}$ & $\begin{array}{c}\text { Zoochory } \\
(\%)\end{array}$ & $\begin{array}{l}\text { Autochory } \\
(\%)\end{array}$ & $n$ & $\begin{array}{c}\text { Dry } \\
\text { season }\end{array}$ & $\begin{array}{l}\text { Rainy } \\
\text { season }\end{array}$ \\
\hline 1 & Pernambuco (Brazil) & - & 7 & 549 & $\mathrm{~T}, \mathrm{~S}, \mathrm{CL}, \mathrm{CT}, \mathrm{H}$ & 33 & $36^{a}$ & $31^{\mathrm{a}}$ & 42 & ane (47) & zoo $(38)$ \\
\hline 2 & Guanacaste (Costa Rica) & - & 4 & 1533 & $\mathrm{~T}$ & 31 & $51^{\mathrm{b}}$ & 18 & 104 & ane (43) & zoo $(90)$ \\
\hline 5 & $\begin{array}{l}\text { Foothills of Urucum } \\
\qquad \text { (Brazil) }\end{array}$ & $150-200$ & 6 & 1400 & Canopy $\mathrm{T}$ & 27 & 53 & 20 & 56 & ane-aut & zoo \\
\hline 6 & Caatinga (Brazil) & 500 & 5 & 803 & - & 32 & 26 & 42 & 19 & ane & zoo \\
\hline 7 & Cerrado (Brazil) & - & 6 & 1300 & - & 30 & 52 & 18 & 271 & ane & zoo \\
\hline 10 & Caatinga (Brazil) & - & $3-7$ & $240-900$ & $\mathrm{~T}, \mathrm{~S}$ & - & $39.8^{\mathrm{d}}$ & - & 103 & - & - \\
\hline 11 & S Ecuador & $160-800$ & 5 & $300-700$ & $\mathrm{~T}, \mathrm{~S}$ & 28 & 54 & $18^{\mathrm{a}, \mathrm{e}}$ & 160 & ane (59) & zoo (68) \\
\hline
\end{tabular}

References: 1, Griz and Machado (2001); 2, Frankie et al. (1974); 3, Wikander (1984); 4, Vasconcelos (2006); 5, Ragusa-Netto and Silva (2007); 6, Machado and Barros (1997); 7, Gottsberger and Silberbauer-Gottsberger (1983); 8, Justiniano and Fredericksen (2000); 9, Batalha and Mantovani (2000); 10, Oliveira and Moreira (1992); 11, this study.

${ }^{a}$ Including passive autochory.

${ }^{\mathrm{b}}$ Fleshy fruits.

${ }^{c}$ Dispersal by zoochory and passive autochory.

${ }^{\mathrm{d}}$ Dispersal by vertebrates.

${ }^{\mathrm{e}}$ Including polychory.

escape from competition in the immediate vicinity will only be achieved if the parent plant is small. We, and other researchers before (Griz \& Machado 2001), found some exceptions to this pattern. One possible explanation for the presence of autochory between taller plants may be that secondary dispersal agents that are not considered in this study, (e.g., water, ingestion by herbivores, or handling rodents or insects) act to move seeds at farther distances (Wenny 2005). Another possibility is that tall trees can disperse seeds at greater distances. For example, Hura crepitans has explosive capsules that can release the seeds up to $14 \mathrm{~m}$ away (Van der Pijl 1969).

Our results demonstrate with quantitative data and through direct relation that environmental conditions affect the structure of seed dispersal spectrum in a Neotropical dry forest community. Thus, anemochory was associated with sites that had higher annual precipitation and lesser variation in the annual temperature range. This trend is contrary to what has been reported for other Neotropical dry forests (Daubenmire 1972, Gentry 1982, Howe \& Smallwood 1982, Tabarelli et al. 2003, Ragusa-Netto \& Silva 2007). For example, Howe and Smallwood (1982) found a significant negative correlation between the percentages of wind dispersed species and annual precipitation in six different communities. This discrepancy could be due to those studies considering only frequency of dispersal syndromes at the species level without accounting for individual species abundance, in opposition to our four corner statistics.

The exclusive association of endozoochorous species with slope sites is difficult to rationalize. A relationship between dispersal by vertebrates and increasing moisture and soil fertility has been reported for temperate plant communities (Milewski 1986; Willson et al. 1989, 1990; Bronstein et al. 2007). Similarly, some researchers have shown a possible association between the proportion of zoochorous species and the quantity and actual duration of rainfall (Frankie et al. 1974, Griz \& Machado 2001, Tabarelli et al. 2003, Ragusa-Netto \& Silva 2007). According to Bullock (1995), sites that are drier and moister because of local topography, support lower and higher frequencies of zoochorous tree species, respectively. Within our study area, the soils in slope sites vary largely in the ranges of moisture, soil organic matter, carbon and nitrogen, whereas soils in ridge sites are more homogeneous and, on average, have lower values for these parameters. This could explain the observed pattern.

Despite being an uncommon strategy in the studied community, epizoochory showed an association with sites of lower precipitation and lower annual temperature range. Other studies have shown a tendency of epizoochorous species to associate with open and dry habitats (Gottsberger \& Silberbauer-Gottsberger 1983, Sørensen 1986, Willson et al. 1990, Mori \& Brown 1998). This trend, together with 
the association found between these species and ridge sites may partially reflect the availability of dispersal agents in those areas (Gottsberger \& Silberbauer-Gottsberger 1983, Willson \& Traveset 2000) and possibly indicate a better adhesion ability under dry conditions.

We found an association between dispersal syndromes and fruiting phenology, which is consistent with those reported in other Neotropical dry forests (Frankie et al. 1974, Bullock 1995, Batalha \& Mantovani 2000, Justiniano \& Fredericksen 2000, Griz \& Machado 2001) (Table 4). In anemochorous species, the peak of fruiring was observed during the dry season, whereas in zoochorous species it was observed in the rainy season. This phenological segregation of dispersal syndromes mirrored the environmental correlates described above. This suggests that spatio-temporal changes in physical conditions may be related to important ecological factors for dispersal. The loss of leaves of most species during the dry season allows a higher wind circulation, even in the understory, thereby facilitating anemochory (Wikander 1984, IbarraManríquez et al. 1991, Griz \& Machado 2001). Moreover, for other Neotropical dry forest the dominance of zoochory during the rainy season has been linked to seasonality in temperature and water availability, which set limits on development time and maturation of fruits (Herrera \& Pellmyr 2002). It is also worth considering that in these ecosystems, animal dispersal agents are more active during the rainy season. These patterns can influence the evolution of fruiting seasons (Wheelwright \& Janson 1985, Griz \& Machado 2001, Herrera \& Pellmyr 2002).

However, our results on fruiting phenology should be considered with caution because data for some species were obtained only from herbarium specimens, and this does not guarantee that the recorded data would cover the actual fruiting period for all species (Borchert 1996).

Summarizing, the observed patterns suggest that the seed dispersal spectrum of dry forests of Southern Ecuador is strongly affected by spatio-temporal changes in environmental conditions. Moreover, these forests hold a large variety of plants requiring animal assistance to seed dispersal. However, fruit availability is limited by fruiting seasonality and a low frequency of individuals of zoochorous species. In altered habitats, like those studied here, maintaining seed dispersal processes is important to preserve the connectivity among patches and foster the recolonization of degraded zones. Our identification of general patterns will help to understand the ecology of this ecosystem, to determine which species are more susceptible to environmental changes and to inform restoration projects.

\section{ACKNOWLEDGMENTS}

This research was financed by the AECID project A/024796/09, REMEDINAL2 and Universidad Técnica Particular de Loja (UTPL). The authors wish to thank $\mathrm{C}$. I. Espinosa and O. Cabrera for access to floristic composition and environmental data. Thanks to the staff of Herbarium UTPL and thanks Bolivar Merino for their help in species determinations and to Paul Cahén for the English language revision. Thanks to three anonymous referees whose constructive criticism improved a previous version of the manuscript.

\section{SUPPORTING INFORMATION}

Additional Supporting Information may be found in the online version of this article:

APPENDIX S1. Growth forms and diaspore traits for 160 species in South Ecuadorian Dry Forests.

TABLE S1. Pseudo-F and Pearson $\chi^{2}$ statistics computed to measure the link between dispersal traits and environmental variables in the fourth-corner analysis.

TABLE S2. Synthesis of the results of the fourth-corner analysis, in which seed dispersal traits are related to environmental conditions.

FIGURE S1. Location of study area.

Please note: Wiley-Blackwell is not responsible for the content or functionality of any supporting materials supplied by the authors. Any queries (other than missing material) should be directed to the corresponding author for the article.

\section{LITERATURE CITED}

Agurrre, Z., AND L. KVIST. 2005. Composición florística y estado de conservación de los bosques secos del sur-occidente del Ecuador. Lyonia 8: $41-67$.

AgutrRe, Z., L. Kvist., AND O. SÁNCHEZ. 2006a. Bosques secos en Ecuador y su diversidad. In R. M. , Moraes, B. Øllgaard, L. P. Kvist, F. Borchsenius, and H. Balslev (Eds.). Botánica Económica de los Andes Centrales, pp. 162-187. Universidad Mayor de San Andrés, La Paz, Bolivia.

Aguirre, Z., R. Linares-Palomino, And L. Kvist. 2006b. Especies leñosas y formaciones vegetales en los bosques estacionalmente secos de Ecuador $y$ Perú. Arnaldoa 13: 324-350.

Arbeláez, M. V., and A. Parrado-Rosselli. 2005. Seed dispersal modes of the sandstone plateau vegetation of the Middle Caquetá River Region, Colombia Amazonia. Biotropica 37: 64-72.

Aubin, I., M. Ouellette, P. Legendre, C. Messier, and A. Bouchard. 2009. Comparison of two plant functional approaches to evaluate natural restoration along an old-field-deciduous forest chronosequence. J. Veg. Sci. 20: 185-198.

Augspurger, C. 1986. Morphology and dispersal potential of wind-dispersed diaspores of Neotropical trees. Am. J. Bot. 73: 353-363.

BatalHa, M. A., AND W. MaNTovani. 2000. Reproductive phenological patterns of Cerrado plant species at the Pé-de-Gigante Reserve (Santa Rita do Passa Quatro, $S_{p}$, Brazil): A comparison between the herbaceous and woody floras. Rev. Bras. Biol. 60: 129-145.

Best, B. J., AND M. KessLeR. 1995. Biodiversity and Conservation in Tumbesian Ecuador and Peru. BirdLife International, Cambridge, UK.

Borchert, R. 1996. Phenology and flowering periodicity of Neotropical dry forest species: Evidence from herbarium collections. J. Trop. Ecol. 12: 65-80.

Bronstein, J. L., I. Izhak, R. Nathan, J. J. Tewksbury, O. Spiegel, A. Lotan, AND O. AltSTEIN. 2007. Fleshy-fruited plants and frugivores in desert ecosystems. In A. J. Dennis, E. W. Schupp, R. J. Green, and D. A. Westcott (Eds.). Seed Dispersal: Theory and its Application in a Changing World, pp. 148-177. CAB International, Oxford, UK.

Bullock, S. H. 1995. Plant reproduction in Neotropical dry forests. In S. Bullock, H. Mooney, and E. Medina (Eds.). Seasonally Dry Tropical Forests, pp. 277-297. Cambridge University Press, Cambridge, UK.

Butler, D. W., R. J. Green, D. Lamb, W. J. F. McDonald, and P. I. Forster. 2007. Biogeography of seed-dispersal syndromes, life-forms and seed sizes among woody rain-forest plants in Australia's subtropics. J. Biogeogr. 34: 1736-1750. 
Chen, J., T. Fleming, L. Zhang, H. WANG, AND Y. LiU. 2004. Patterns of fruit traits in a tropical rainforest in Xishuangbanna, SW China. Acta Oecol. 26: $157-164$.

Cousens, R., C. Dytham, and R. Law. 2008. Dispersal in Plants. A Population Perspective. Oxford University Press Inc., New York, New York.

Daubenmire, R. 1972. Phenology and other characteristics of tropical semideciduous forest in north-western Costa Rica. J. Ecol. 60: 147-170.

Dray, S., A. B. Dufour, And D. Chessel. 2007. The ade4 package-II: Two-table and K-table methods. R. News 7: 47-52.

Dray, S., AND P. Legendre. 2008. Testing the species traits-environment relationships: The fourth-corner problem revisited. Ecology 89: 3400-3412

Espinosa, C. I., O. Cabrera, A. Luzuriaga, and A. Escudero. 2011. What factors affect diversity and species composition of endangered Tumbesian dry forests in southern Ecuador? Biotropica 43: 15-22.

Frankie, G. W., H. G. Baker, And P. A. Opler. 1974. Comparative phenological studies of trees in tropical wet and dry forests in the Lowlands of Costa Rica. J. Ecol. 62: 881-919.

GenTRY, A. H. 1982. Patterns of Neotropical plant species diversity. Evol. Biol. 15: 1-84.

GotTsberger, G., and I. Silberbauer-Gottsberger. 1983. Dispersal and distribution in the Cerrado vegetation of Brazil. Sonderb. Naturwiss. 7: 325-352.

GRIZ, L. M. S., AND I. C. S. MACHADO. 2001. Fruiting phenology and seed dispersal syndromes in Caatinga, a tropical dry forest in the northeast of Brazil. J. Trop. Ecol. 17: 303-321.

HarLING, G., AND L. ANDerson (Eds.). 1977-2007. Flora of Ecuador. Board Editorial, Berlings, Arlov, Sweden.

Herrera, C. M., and O. Pellmyr. 2002. Plant-Animal Interactions. An Evolutionary Approach. Blackwell Publishing, Oxford, UK.

Hijmans, R. J., S. E. Cameron, J. L. Parra, P. G. Jones, and A. Jarvis. 2005. Very high resolution interpolated climate surfaces for global land areas. Int. J. Climatol. 25: 1965-1978.

Howe, H. F., AND J. Smallwood. 1982. Ecology of seed dispersal. Annu. Rev. Ecol. Syst. 13: 201-228.

Howe, H. F., AND L. C. WestLey. 1988. Mechanics and ecology of mutualism. In H. F. Howe and L. C. Westley (Eds.). Ecological Relationships of Plants and Animals, pp. 107-160. Oxford University Press, Oxford, UK.

Hughes, L., M. Dunlop, K. French, M. Leishman, B. Rice, L. Rodgerson, AND M. Westoby. 1994. Predicting dispersal spectra: A minimal set of hypotheses based on plant attributes. J. Ecol. 82: 933-950.

Ibarra-Manríquez, G., B. Sánchez-Garfias, and L. González-García. 1991. Fenología de lianas y árboles anemocoros en una selva cálido-húmeda de México. Biotropica 23: 242-254.

JANSON, C. H. 1983. Adaptation of fruit morphology to dispersal agents in a Neotropical forest. Science 219: 187-189.

Jordano, P. 2000. Fruits and frugivory. In M. Fenner (Ed.). Seeds: The Ecology of Regeneration in Plant Communities (2nd edition), pp. 125-165. CABI Publishing, Wallingford, UK

JøRGENSEN, P. M., AND S. LFóN-Ý́NeZ (Eds.). 1999. Catalogue of the Vascular Plants of Ecuador. Monogr. Syst. Bot. Missouri Bot. Gard. 75: 1-1182. i-viii.

Justintano, M., and T. Fredericksen. 2000. Phenology of tree species in Bolivian dry forests. Biotropica 32: 276-281.

KNIGHT, R. S. 1986. Interrelationships between fruit types in southern African trees and environmental variables. J. Biogeogr. 13: 99-108.

LEGENDRE, P., R. GALZIN, AND M. HARMELIN-VIVIEN. 1997. Relating behavior to habitat: Solutions to the fourth-corner problem. Ecology 78: 547-562.

LINK, A., AND P. R. STEVENSON. 2004. Fruit dispersal syndromes in animal disseminated plants at Tinigua National Park, Colombia. Rev. Chil. Hist. Nat. 77: 319-334.
Machado, I., AND L. Barros. 1997. Phenology of Caatinga species at Serra Talhada, PE, Northeastern Brazil. Biotropica 29: 57-68.

MiLEWSKT, A. V. 1986. A comparison of bird-plant relationships in southern Australia and southern Africa. In H. A. Ford and D. C. Paton (Eds.). The Dynamic Partnership: Birds and Plants in Southern Africa, pp. 111-118. D.J. Woolman Govt. Printer, Adelaide.

Morales, J. M., ANd T. A. Carlo. 2006. The effects of plant distribution and frugivore density on the scale and shape of dispersal kernels. Ecology 87 ; $1489-1496$

Morr, S., AND J. Brown. 1998. Epizoochorous dispersal by barbs, hooks, and spines in a lowland moist forest in Central French Guiana. Brittonia 50: 165-173.

Navarro, T., V. Pascual, C. L. Alados, and B. Cabezudo. 2009. Growth forms, dispersal strategies and taxonomic spectrum in a semi-arid shrubland in SE Spain. J. Arid Environ. 73: 103-112.

Oliveira, P. E. A. M. DE, AND A. G. Moreira. 1992. Anemocoria em espécies de Cerrado e Mata de Galeria de Brasília, DF. Rev. Bras. Bot. 15: 163-174.

Pennington, T. D., C. Reynel, And A. Daza. 2004. Illustrated Guide to the Trees of Peru. DH Books, England, UK.

Ragusa-NetTo, J., AND R. R. SILVA. 2007. Canopy phenology of a dry forest in western Brazil Braz. J. Biol. 67: 569-575.

Schulze, E., E. Beck, aNd K. Müller-Hohenstein. 2002. Plant Ecology. Springer, Berlin.

Sørensen, A. E. 1986. Seed dispersal by adhesion. Annu. Rev. Ecol. Syst. 17: 443-463.

SpjuT, R. W. 1994. A Systematic Treatment of Fruit Types. The New York Botanical Garden, New York, New York.

Strykstra, R. J., R. M. BekKer, ANd J. Van Andel. 2002. Dispersal and life span spectra in plant communities: A key to safe site dynamics, species coexistence and conservation. Ecography 25: 145-160.

Tabarelli, M., A. Vicente, and D. C. A. Barbosa. 2003. Variation of seed dispersal spectrum of woody plants across a rainfall gradient in northeastern Brazil. J. Arid Environ. 53: 197-210.

VAn der PIJL, L. 1969. Principles of Dispersal in Higher Plants. Springer-Verlag, Berlin.

VAsconcelos, S. F. D. 2006. Fenologia e síndromes de dispersao de espécies arbustivas e arbóreas acorrentes em uma área de carrasco no planalto da Ibiapaba, Ceará. MSc dissertation, Universidade Federal de Pernambuco, Brazil, pp. 61.

Vízquez, M. A., M. LarreA, L. Sú́rez, ANo P. Ojeda (Eds.). 2001. Biodiversidad en los bosques secos del suroccidente de la provincia de Loja: un reporte de las evaluaciones ecológicas y socioeconómicas rápidas. EcoCiencia, MAE, Herbario Loja y Proyecto Bosque Seco, Quito, Ecuador.

WENNY, D. 2001. Advantages of seed dispersal: A re-evaluation of directed dispersal. Evol. Ecol. Res. 3: 51-74.

WENNY, D. 2005. Post-dispersal seed fate of some cloud forest tree species in Costa Rica. In P-M. Forget, J. E. Lambert, P. E. Hulme, and S. B. Vander Wall (Eds.). Seed Fate: Predation, Dispersal and Seedling Establishment. CAB International, Oxford, UK.

Wheelwright, N., AND C. Janson. 1985. Colors of fruit displays of birddispersed plants in two tropical forests. Am. Nat. 126: 777-799.

Wirander, T. 1984. Mecanismos de dispersión de diásporas de una selva decidua en Venezuela. Biotropica 16: 276-283.

WiLlson, M. F., A. K. IRVINE, AND N. G. WaLSH. 1989. Vertebrate dispersal syndromes in some Australian and New Zealand plant communities, with geographic comparisons. Biotropica 21: 133-147.

WILLSON, M. F., B. L. Rice, AND M. Westoby. 1990. Seed dispersal spectra: A comparison of temperate plant communities. J. Veg. Sci. 1: 547-562.

Willson, M. F., and A. Traveset. 2000. The ecology of seed dispersal. In M. Fenner (Ed.). Seeds: The Ecology of Regeneration in Plant Communities (2nd edition), pp. 85-110. CABI Publishing, Oxford, UK. 